\title{
JMM UNRAM

\section{PERSEPSI WISATAWAN MUSLIM TERHADAP SARANA PENUNJANG WISATA HALAL DIKAWASAN DESA SEMBALUN LAWANG LOMBOK TIMUR}

\author{
Sri Wahyulina ${ }^{1}$, Sri Darwini' ${ }^{2}$, Weni Retnowati ${ }^{3}$, Sri Oktaryani ${ }^{4}$ \\ Magister Manajemen Universitas Mataram \\ sriwahyulina@yahoo.co.id
}

\begin{abstract}
The purpose of this research was to explore the perception of Muslim Travelers toward Halal Tourism supporting facilities on the Sembalun Lawang village. The research method that used in this research was descriptive method. This research shown the Toilet, Trash and places of worship are becoming the most important means of desired by the tourists who visit the Sembalun regions. The researcher found the condition of the Hotel or other accommodation danTempat Worship is there in halal tourism Sembalun regions, East Lombok Regency is very good compared with the condition of the other supporting facilities. The travelers feel facilities that easy to reach within in the Sembalun Lawang are worship place, the Hotel/accommodation/Lodging, restaurant/dining and two wheeled vehicle parking Area. The results of this research suggest to Government and societies of Sembalun Lawang immediately provide toilets and Trash at every attraction in the Sembalun Lawang. The Government should immediately set up hotels and other akodomasi so that sufficient for the number of tourists coming to the Sembalun Lawang and not to interfere with the natural landscape Sembalun regions as the main attraction of this area. Faslilitas parking for tour buses should be immediately provided. For the banking and Government should cooperate in facilitating ATM for tourists to take the cash.
\end{abstract}

Keywords: Perception, Travellers, Muslims, A Means Of Supporting Tourism, Halal, Sembalun Regions Mace

\section{PENDAHULUAN}

Pariwisata adalah salah satu industri besar di dunia. Menurut Dewan Perjalanan dan Pariwisata Dunia (2016), pendapatan dari belanja pariwisata menyumbang 9,8 persen terhadap produk domestik bruto dunia (PDB). Untuk Nusa Tenggara Barat (NTB), pariwisata harus diakui memiliki peranan penting bagi pembangunan daerah. Berdasarkan data BPS, NTB mencatat kontribusi pendapatan sektor pariwisata masih belum signifikan. Sektor Penyediaan Akomodasi Makan dan Minum hanya menyumbang 2,4 persen, cukup rendah bila dibandingkan dengan provinsi pariwisata lain seperti Bali dan Yogyakarta. Oleh karena itu, masih banyak potensi yang dapat digali.

Salah satu upaya untuk mengatasi permasalahan pariwisata NTB adalah dengan melakukan inovasi pemasaran.Menarik segmen pasar baru adalah salah satu di antara strategi pemasaran untuk bisnis pariwisata agar pariwisata NTB tetap dan berkembang dalam kompetisi yang tinggi ini.Sebuah segmen yang tumbuh dari industri pariwisata disebut pariwisata halal (Henderson, 2010).Pariwisata halal adalah ketika seorang musafir Muslim memilih untuk mematuhi iman mereka dan ajaranajarannya sementara perjalanan dan penginapan di luar negeri. 


\section{$J M M$ UNRAM

Sebagai wilayah dengan penduduk bermayoritas agama Islam (97 persen), NTB jelas memiliki potensi yang besar untuk menarik wisatawan Muslim.Pengakuan dunia tentang kemampuan wisata NTB tidak diragukan lagi.Ini terlihat dari dinobatkannya Lombok sebagai pemenang penghargaan World Halal Travel Summit 2015 di Abu Dhabi, Uni Emirat Arab. Sementara itu pada 7 Desember 2016 lalu, World Halal Tourism Award (WHTA) 2016 telah mengumumkan pemenang kategori World's Best Halal Honeymoon Destination 2016 adalah kawasanpedesan Sembalun atau yang lebih dikenal dengan nama Sembalun Balley Region. Desa di Lombok Timur ini memang sudah menjadi destinasi favorit para turis lokal maupun mancanegara dan memang biasa dijadikan "honeymoon destination" favorit.

Bulan Maret 2017 menjadi bulan yang mengecewakan bagi pelaku wisata dan masyarakat NTB, Raja Salam bin Abdul Aziz dari Arab Saudi beserta 1500 orang rombongannya yang notebene Muslim justru memilih berlibur di Bali. Apa yang terjadi dengan Lombok? Apa kekurangan Lombok? Sumber dari Kementerian Luar Negeri melalui Kepala Dinas Kebudayaan dan Pariwisata NTB L. M. Faozal menyatakan bahwa Bali memiliki sarana pariwisata yang lengkap dibanding NTB (suarantb.com, 2017).Persoalan sarana menjadi penting bagi wisatawan mengingat mereka berpergian jauh untuk mendapatkan pengalaman berbeda.Dalam penyediaan sarana bagi wisatawan sebagai konsumen sering kali terjadi kesenjangan atau perbedaan persepsi antara produsen dengan konsumen.Selain itu budaya dan karakter konsumen yang berbeda juga ikut menyebabkan permasalahan pemasaran (Kotler dan Amstrong, 2015).

Kegiatan pariwisata di kawasan Sembalun sebagai sentra wisata halal di Pulau Lombok ini harus mampu beradaptasi terhadap semua tuntutan perubahan dengan selalu mendengar suara dari berbagai pihak yang berkepentingan khususnya wisatawan yang memiliki preferensi yang berbeda dalam memilih objek-objek wisata yang akan dikunjungi. Preferensi wisatawan timbul dari keberagaman fasilitas dan kegiatan wisata yang memenuhi kebutuhan wisatawan saat melakukan perjalanan wisata. Preferensi wisatawan menjadi dasar dalam memperhitungkan keinginan dan kebutuhan akan pelayanan fasilitas wisata yang akan diterima.

Adanya kebutuhan untuk mengembangkan pariwisata di di kawasan Sembalun, wisatawan menjadi salah satu aspek penting yang perlu menjadi pertimbangan dalam pengembangan pariwisata. Untuk itu perlu diperhatikan preferensi wisatawan agar cara pengembangan kawasan pariwisata yang sesuai dengan keinginan wisatawan diketahui secara tepat.

Sarana wisata merupakan salah satu unsur penting pembentuk produk wisata yang berperan untuk menunjang kemudahan dan kenyamanan wisatawan dalam perjalanan wisata.Pemasaran produk pariwisata halal sangat tergantung pada sarana penunjangnya.Namun Wisatawan Muslim tidak hanya dari Timur Tengah dan banyak perbedaan di antara wisatawan tersebut sehingga mungkin saja terjadi perbedaan persepsi.Untuk itu Persepsi wisatawan terhadap sarana penunjang wisata halal di kawasan Desa Sembalun LawangLawang Lombok Timur perlu diketahui sebagai masukan untuk masyarakat setempat agar dapat menangkap peluang usaha pariwisata halal.

\section{KAJIAN LITERATUR}

Dalam Undang-undang RI nomor 10 tahun 2009 tentang Kepariwisataan, pengertian pariwisata adalah sebagai berikut : "Pariwisata adalah berbagai macam kegiatan wisata dan didukung berbagai fasilitas serta layanan yang disediakan oleh masyarakat, pengusaha, dan pemerintah.

Pengertian wisatawan menurut Undang-Undang Republik Indonesia No 9 tentang Kepariwisataan, Bab I berisi tentang Ketentuan Umum Pasal 1 ayat 1 dan 2 dirumuskan sebagai berikut: 


\section{$J M M$ UNRAM

Wisata adalah kegiatan perjalanan atau sebagian dari kegiatan tersebut yang dilakukan secara sukarela serta bersifat sementara untuk menikmati objek dan daya tarik wisata.Sedangkan wisatawan adalah orang yang melakukan kegiatan wisata.

Dari definisi di atas disimpulkan bahwa wisatawan merupakan pelaku (konsumen) yang melakukan kegiatan di luar aktivitas sehari-hari untuk melakukan kunjungan wisata ataupun suatu perjalanan yang direncanakan untuk mendapatkan kepuasan bagi diri sendiri, sedangkan

Definisi pariwisata syariah adalah kegiatan yang didukung oleh berbagai fasilitas serta layanan yang disediakan masyarakat, pengusaha, pemerintah, dan pemerintah daerah yang memenuhi ketentuan syariah (Kemenpar, 2012). Pariwisata syariah dimanfaatkan oleh banyak orang karena karakteristik produk dan jasanya yang bersifat universal.Produk dan jasa wisata, objek wisata, dan tujuan wisata dalam pariwisata syariah adalah sama dengan produk, jasa, objek dan tujuan pariwisata pada umumnya selama tidak bertentangan dengan nilai-nilai dan etika syariah. Jadi pariwisata syariah tidak terbatas hanya pada wisata religi.Sedangkan menurut Sapta Nirwandar (2015) dalam (Achyar, 2015) keberadaan wisata halal sebagai berikut:

Halal tourism adalah extended services. Kalau tidak ada dicari, kalau ada, bisa membuat rasa aman. Wisata halal bisa bergandengan dengan yang lain. Sifatnya bisa berupa komplementer, bisa berupa produk sendiri. Misalnya ada hotel halal, berarti membuat orang yang mencari hotel yang menjamin kehalalan produknya akan mendapatkan opsi yang lebih luas. Ini justru memperluas pasar, bukan mengurangi.Dari yang tadinya tidak ada, jadi ada".

Para ahli mendefinisikan perilaku wisatawan, menurut Morrisan (2007:64) perilaku wisatawan adalah proses dan kegiatan yang terlibat ketika orang mencari, memilih, menggunakan, mengevaluasi, dan membuang produk dan jasa untuk memuaskan kebutuhan dan keinginan mereka. Menurut Loudon dan Della Bitta (Buchari Alma, 2008:236) "Tourist behavior may be defined as the decision process and physical activity individuals engage in when evaluating, acquiring, using, or disposing of goods and services". (Perilaku wisatawan adalah proses pengambilan keputusan dan kegiatan fisik individuindividu yang semuanya ini melibatkan individu dalam menilai, mendapatkan, menggunakan, atau mengabaikan barang-barang dan jasa-jasa).

Menurut Kotler dan Keller (2009:189) mengemukakan tentang definisi perilaku wisatawan yaitu, "Tourist behaviour is study of how individuals, groups, and organizations select, buy, use, and dispose of goods, services, ideas, or experiences to satisfy their needs and wants". Dapat dijelaskan bahwa pemasar atau perusahaan harus memahami tentang apa yang menjadi kebutuhan dan keinginan wisatawan baik itu berupa jasa, ide-ide, atau pengalaman yang mampu memuaskan keinginan dan kebutuhan wisatawan.

Perilaku wisatawan dipengaruhi oleh beberapa faktor seperti yang dikemukakan Kotler dan Keller (2009:190) yaitu, faktor budaya, faktor sosial, faktor personal dan faktor psikologi. Faktor-faktor tersebut dapat dijelaskan sebagai berikut:

1. Faktor Budaya

Budaya, subbudaya dan kelas sosial merupakan faktor yang paling banyak mempengaruhi perilaku kunjungan pada wistawan.

2. Faktor Sosial

Faktor sosial sebagai tambahan dari faktor budaya, faktor sosial terdiri dari referensi keluarga, kelompok, dan aturan sosial dan status berdampak pada perilaku kunjungan.

3. Faktor Personal 


\section{JMM UNRAM

Keputusan berkunjung juga dipengaruhi oleh karakteristik personal, yang termasuk dalam kategori ini adalah umur dan daur hidup, pekerjaan dan ekonomi, kepribadian dan konsep diri, dan gaya hidup dan nilai.

4. Faktor Psikologi

Langkah utama dalam memahami perilaku wisatawan adalah model tanggapan rangsangan. Pemasar dan lingkungan mempengaruhi untuk masuk dalam kesadaran wisatawan dan mengatur proses kejiwaannya yang menggabungkan dengan karakteristik keyakinan wisatawan untuk menghasilkan proses keputusan dan keputusan berkunjung.

Sarana wisata merupakan kelengkapan daerah tujuan wisata yang diperlukan untuk melayani kebutuhan wisatawan dalam menikmati perjalanan wisatanya (Warpani, 2006).Berbagai sarana wisata yang harus disediakan di daerah tujuan wisata ialah hotel, biro perjalanan, alat transportasi, restoran dan rumah makan serta sarana pendukung lainnya. Tidak semua objek wisata memerlukan sarana yang sama atau lengkap. Pengadaan sarana wisata tersebut harus disesuaikan dengan kebutuhan wisatawan.

$\begin{array}{ll}\text { 1. } & \text { Akomodasi } \\ \text { 2. } & \text { Tempat Makan } \\ \text { 3. } & \text { Tempat Belanja }\end{array}$

\section{METODE PENELITIAN}

Jenis penelitian yang dilakukan bersifat deskriptif. Menurut Nazir (2005), penelitian deskriptif adalah suatu metode dalam menganalisi suatu kelompok manusia, suatu objek, suatu set kondisi, suatu sistem pemikiran, ataupun suatu kelas pristiwa pada masa sekarang. Dalam hal ini, penelitian deskriptif digunakan untuk mendapatkan gambaran mengenai fasilitas pendukung jasa wisata Halal di Desa Sembalun Lawang.

Metode yang digunakan dalam penelitian ini yaitu deskriptif dan evaluatif. Metode deskriptif merupakan suatu metode analisis yang digunakan untuk melukiskan atau menggambarkan segenap fakta atau karakteristik populasi tertentu secara sistematis, aktual, dan cermat (Arikunto 2006:239 dalam Callista dan Putro, 2013). Metode Evaluatif yaitu metode analisis dengan menggunakan suatu instrumen tertentu untuk membantu dalam melakukan suatu analisis (Callista dan Putro, 2013)

Populasi dari penelitian ini adalah wisatawan Muslim yang berkunjung ke Propinsi NTB. Dinas Kebudayaan dan Pariwisata (Disbudpar) NTB mencatat angka kunjungan wisatawan ke Lombok dan Sumbawa sepanjang tahun 2013 mencapai 1.357.602 kunjungan, terdiri dari 565.944 wisatawan mancanegara, dan 791.658 wisatawan Nusantara atau domestik (Lomboktoday.co.id, 2013).

Penelitian ini menggunakan metode nonprobability sampling yaitu metode purposive sampling, dimana sampel yang diambil dalam penelitian ini ditentukan berdasarkan syarat-syarat tertentu sesuai dengan tujuan penelitian (Mustafa, 2000). Untuk itu maka peneliti menentukan syarat-syarat anggota populasi yang dapat turut menjadi sampel yaitu sebagai berikut :

1. Wisatawan domestik

2. Warga Negara Indonesia

3. Pernah berkunjung ke Desa Sembalun Lawang, Lombok Timur, minimal 1 kali

4. Berusia di atas 17 tahun

Untuk menentukan jumlah sampel maka ada beberapa aspek yang dipertimbangkan yaitu:

1. Derajat Keseragaman Populasi (degree of homogenity), mengingat adanya kesamaan di antara wisatawan Nusantara terutama dari segi sosial budaya. 


\section{$J M M$ UNRAM

2. Penelitian ini akan menggunakan teknik analisis data dengan statistik deskriptif dan statistik inferensial (analisis conjoint), maka ukuran sampelnya harus cukup besar dan representatif.

Selain mempertimbangkan faktor-faktor di atas, sesuai dengan saran sejumlah penulis buku metode penelitian menyarankan digunakannya rumus tertentu untuk menentukan berapa besar sampel yang harus diambil dari populasi, maka penulis menggunakan Rumus Slovin.Hal ini mengingat ukuran populasi penelitian ini diketahui dengan pasti.Berikut ini Rumus Slovin yang digunakan menghitung sampel penelitian ini untuk kedua tahap.

$$
\mathrm{n}=\frac{\mathrm{N}}{1+-\mathrm{Ne}^{2}}
$$

Keterangan

$\mathrm{n}=$ ukuran sampel

$\mathrm{N}=$ ukuran populasi

$\mathrm{e}=$ kelonggaran ketidaktelitian karena kesalahan pengambilan sampel yang ditololerir adalah $10 \%$.

Sehingga :

$$
\mathrm{n}=\frac{791658}{1+791658(10 \%)^{2}}
$$

Maka didapatkan jumlah sampel untuk setiap tahap penelitian ini adalah sebanyak 99.98737 dan dibulatkan menjadi 100 sehingga total seluruh responden penelitian ini berjumlah 100 orang.

Dalam penelitian ini Metode Pengumpulan Datayang digunakan adalah sampel survey. Alasan menggunakan metode sampelsurvey dalam pengumpulan data karena ukuran populasi begitu besar.

Teknik Pengumpulan Data yang digunakan adalah :Teknik Wawancara, Teknik observasi dan Teknik Angket. Alat pengumpulan data yang digunakan dalam penelitian ini yaitu kuesioner, yaitu kumpulan pertanyaan yang disusun oleh peneliti untuk menghimpun informasi sesuai dengan permasalahan yang dikaji.

Jenis data yang digunakan adalah Data Kualitatif dan Data Kuantitatif Sumber data penelitian ini adalah data primer yang diambil dari responden melalui proses pengumpulan data dan data sekunder yang diambil dari berbagai sumber baik itu naskah yang terkait, situs internet dan data BPS.

Penelitian ini akan mendeskripsikan tiga variabel yang terdiri dari variabel utama dan variabel pendukung keberadaan lokasi wisata Halal di Desa Sembalun Lawang tersebut. Variabel utama dari penelitian ini yaitu Amenities (Fasilitas), Attraction (Daya Tarik) dan Accessibility (Keterjangkauan) lokasi wisata Halal di Desa Sembalun Lawang

Kuesioner yang digunakan dalam penilaian ini menggunakan Skala Likert dengan 5 alternatif jawaban (skala 5) dan skor 1-5 (Djarwanto dan Subagyo, 2006) yang dimodifikasi berdasarkan kepentingan penelitian antara lain:

1. Untuk mengukur persepsi wisatawan tentang bagaimana tingkat kepentingan fasilitas digunakan skala sebagai berikut : Sangat tidak penting (1), Tidak penting (2), Cukup penting (3), Penting (4), dan Sangat penting (5).

2. Untuk mengukur persepsi wisatawan tentang bagaimana kondisi fasilitas yang ada di sekitar lokasi wisata Halal di Desa Sembalun Lawang/spiritual diukur dengan skala sebagai berikut : Sangat Tidak Baik (1), Tidak Baik (2), Cukup Baik (3), Baik (4), dan Sangat Baik (5).

3. Untuk mengukur persepsi wisatawan terhadap kemudahan dalam mencapai tempat lokasi wisata Halal di Desa Sembalun Lawang dan fasilitas yang ada di sekitarnya diukur dengan 


\section{$J M M$ Maret 2018 UNIVERSITAS MATARAM \\ e- issn : 2548-3919}

skala : Sangat Tidak Mudah (1), Tidak Mudah (2), Cukup Mudah (3), Mudah (4), dan Sangat Mudah (5).

Kuesioner yang digunakan dalam penelitian ini merujuk pada kuesioner penelitian Sari (2010) dan Callista dan Putro (2013. Ini disebabkan karena penelitian ini dan penelitian dan Sari (2010) dan Callista dan Putro (2013) memiliki kesamaan yaitu meneliti persepsi wisatawan Halal dan tingkat kepentingan wisatawan terhadap variabel Attraction (Daya Tarik), Amenities (Fasilitas) dan Accessibility (keterjangkauan) lokasi wisata Halal di Desa Sembalun Lawang. Mengingat kuesioner yang digunakan berbasis pada kuesioner yang telah digunakan oleh para peneliti terdahulu maka uji validitas dan reliabilitas tidak perlu dilakukan lagi.

Untuk menganalisis data dalam penelitian ini digunakan Analisis Statistik Deskriptif. Analisis ini digunakan untuk menganilisis data yang didapat dari responden ke dalam persentase berdasarkan karakteristik tertentu yang dimilikinya dengan cara membandingkan jumlah konsumen secara keseluruhan dikalikan $100 \%$ yang kemudian didapat persentase tertinggi sehingga memudahkan dalam membaca data yang diperoleh (Djarwanto dan Subagyo, 2006).

\section{HASIL DAN PEMBAHASAN}

\section{Studi Awal Lapangan}

Dalam Rencana Induk Pembangunan Kepariwisataan Daerah (Ripparda) Provinsi Nusa Tenggara Barat, telah diatur pewilayahan Destinasi Pariwisata Daerah (DPD) menjadi Destinasi Pariwisata Daerah (DPD) Lombok. Destinasi Pariwisata Daerah (DPD). Lombok terdiri dari 4 (empat) Kawasan Strategis Pariwisata Daerah (KSPD) (http://www.disbudpar.ntbprov.go.id/sosialisasi- ripparda-ntb/). Salah satu dari empat Kawasan Strategis Pariwisata Daerah (KSPD) pada Destinasi Pariwisata Daerah (DPD) Lombok adalah RASIMAS-SEMBALUN dan sekitarnya, meliputi Benang Stokel; Gili Sulat; Sembalun; Gunung Rinjani; dan Otak Kokoq. Kawasan ini berada pada wilayah Kabupaten Lombok Tengah dan Kabupaten Lombok Timur, dan diperuntukkan sebagai kawasan wisata agro, wisata pegunungan dan wisata kuliner.

Lembah Sembalun terpilih sebagai Destinasi Bulan Madu Ramah Wisatawan Muslim Terbaik pada ajang World Halal Tourism Award (WHTA) di Abu Dhabi awal Desember 2016. Sebelumnya nama Sembalun memang sudah sangat terkenal di Lombok, bahkan Indonesia sebagai destinasi wisata dengan keindahan pemandangan alamnya yang berada di kaki Gunung Rinjani dan suasana sejuk yang dirasakan ketika kita berada disana, hal ini tentunya sangat tepat dan mendukung untuk memilihnya sebagai tempat berbulan madu. Selain itu Sembalun juga menjadi salah satu pusat agrowisata di NTB, yang mana pengunjung atau wisatawan yang datang dapat memetik buah Stroberi langsung di kebun serta menikmatinya (Lomboklnsider.com, 2017).

Perjalanan menuju Sembalun dari Mataram dapat ditempuh dalam waktu kurang lebih 3 jam, dengan kecepatan normal dan kondisi jalan ramai. Kondisi jalan yang bagus dan mulus namun memiliki medan yang cukup berat dengan tanjakan, turunan dan tikungan tajam sebelum mencapainya akan terbayar lunar dengan keindahan alam Sembalun dan segarnya udara pegunungan disana. Belum lagi bagi penggemar fotografi, begitu banyak titik foto indah dan menarik untuk diabadikan, seperti suasana pegunungan yang diselimuti kabut misalnya (Lomboklnsider.com, 2017).

Seiring perkembangannya sebagai salah satu destinasi wisata andalan bahkan keluar sebagai pemenang Destinasi Bulan Madu Ramah WisatawanMuslim Terbaik versi WHTA 2016, tentunya sarana dan prasarana pendukung yang ada saat ini perlu pembenahan. Begitu banyak penginapan kelas melati hingga hotel bintang yang tersedia, dari pengamatan Lomboklnsider.com beberapa 


\section{$J M M$ UNRAM

waktu lalu, di beberapa penginapan bahkan sekelas hotel bintang sebagai sarana akomodasi yang ada disana belum tersedia arah qiblat, sajadah dan kebutuhan pendukung standar lainnya bagi wisatawan muslim yang menginap, padahal hal ini sangat krusial apalagi Sembalun telah mendapat predikat terbaik tersebut (Lomboklnsider.com, 2017)..

Terkait hal itu Kadis Budpar NTB HL. Moh Faozal mengatakan pihaknya akan segera melakukan koordinasi dengan pelaku industri akomodasi yang ada. "Tentunya hal ini menjadi salah satu konsen kami di Disbudpar, untuk segera melakukan sosialisasi bersama pelaku industri akomodasi yang ada disini, agar hal-hal yang menyangkut kebutuhan standar wisatawan muslim ini dapat terpenuhi," kata Moh. Faozal, disela-sela acara Clean-Up Rinjani di hotel dan restoran Nusantara, beberapa waktu lalu.Faozal menambahkan bahwa Disbudpar NTB sendiri telah membangun sekitar 38lokal dari Mataram, untuk tamu luar banyak dari Malaysia dan Singapura," ungkapnya.Hugeng mengatakan bahkan ketika diadakan acara lomba lari Rinjani100 pada Juli lalu hotel-hotel atau penginapan di seluruh Sembalun penuh, oleh peserta dan keluarganya. Tentunya hal ini menjadi satu kebanggaan bagi Lombok, sekaligus menjadi indikator perkembangan dan kemajuan pariwisata, terutama untuk sport tourism dan destinasi wisata alam.

Yang juga membuat Sembalun demikian terkenal adalah Rinjani sebagai salah satu gunung di NTB dan Indonesia yang sangat digemari oleh para pendaki untuk mendakinya, sedang Sembalun merupakan lembah dan salah satu pintu resmi pendakian selain Senaru, yang ada di kaki Rinjani. Inilah faktor yang saling mendukung antara berkembangnya daerah wisata Sembalun dan Gunung Rinjani.Sembalun juga merupakan pusat tanaman sayur-mayur yang dijual dipasar-pasar tradisional hingga modern di Mataram.

Sementara itu Hugeng Angkoso Joyo ditempat yang sama menjelaskan pihaknya sebagai salah satu pemilik akomodasi di Sembalun yakni Hotel dan Restoran Nusantara, sejauh ini telah berupaya memenuhi standar halal terkait Lombok sebagai salah satu destinasi halal dunia. "Di tempat kami untuk makanan dan minuman halal telah terpenuhi, walaupun belum bersertifikasi MUI, karena dari awal kami berkomitmen mendukung program pemerintah," jelas Hugeng. Hotel dan Restoran Nusantara merupakan salah satu hotel baru dengan 20 kamar, dengan pemandangan alam berlatarbelakang Gunung Rinjani, dengan fasilitas standar hotel bintang (Lomboklnsider.com, 2017).Hampir Semua Sayuran Segar produksi Sembalun yang dijual di Pasar Tradisional dan Modern di Mataram Berasal dari Sembalun.

\section{Karakteristik Responder}

Tabel 4.1Tabulasi Silang Umur dan Jenis kelamin Responden

\begin{tabular}{|c|c|c|c|c|c|}
\hline & \multicolumn{2}{|c|}{5 Jonis kelamin } & \multirow[t]{2}{*}{ Total } \\
\hline & & & Laki-laki & Perempuan & \\
\hline \multirow{7}{*}{ 4. Umur } & Di bawah 20 thn & Count & 8 & 16 & $\begin{array}{r}34 \\
240 \%\end{array}$ \\
\hline & Di bawan 20 tnn & $\%$ of Total & $8.0 \%$ & $16.0 \%$ & $24.0 \%$ \\
\hline & & Count & 28 & & $5200 /$ \\
\hline & $20 \quad 30+\mathrm{hn}$ & $\%$ of Total & $280 \%$ & $24.0 \%$ & $52.0 \%$ \\
\hline & $31-40$ thn & Count & 10 & $88.0 \%$ & $180 \%$ \\
\hline & $41-50$ thn & $\%$ of Total & $10.0 \%$ & $\begin{array}{r}2.0 \% \\
50\end{array}$ & $66.0 \%$ \\
\hline & & $\%$ of Total & & $50.0 \%$ & \\
\hline Total & & Count & $50.0 \%$ & & $100.0 \%$ \\
\hline
\end{tabular}


Ditinjau dari jenis kelaminnya jumlah laki-laki dan perempuan yang menjadi responden seimbang masing-masing 50 persen. Ditinjau dari segi umur usia 30 tahun ke bawah mendominasi. Ini berarti wisatawan yang berkunjung ke Sembalun relatif berusia muda, ini mengingat tantangan lokasi yang berada di pegunungan.Bila ditinjau dari pendidikannya responden usia muda 30 tahun ke bawah sebagian besar berpendidikan SMA sederajat, 42 persen dari responden seluruh responden. Namun di antara mereka juga terdapat 30 persen yang berpendidikan Sarjana

Tingkat Kepentingan Fasilitas 'Wisata halal di Sembalun, Kabupaten Lombok Tim til-

\section{Toko souvenir \\ 15. Tempat hiburan}

4. Zona khusus pedagang kaki lima

11. ATM bank/ penukaran uang

13. Hotel/akomodasi/Penginapan

5. Area parkir parkir bus dan...

2. Restoran/ tempat makan

7. Area parkir kendaraan roda..

6. Area parkir kendaraan roda dua

12. Pelayanan kesehatan

10. Tempat istirahat pengunjung

14. Pos Jaga Polisi/Satpam

1. Tempat ibadah

9. Tempat sampah

8. Toilet
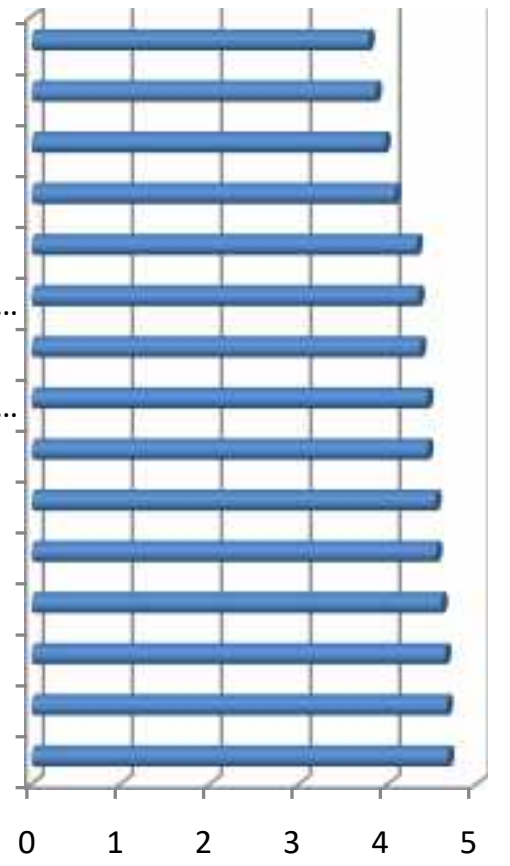

Mean

\section{Gambar4.3 Tingkat Kepentingan Fasilitas Wisata halal di Sembalun, Kabupaten Lombok Timur}

Hasil penelitian ini menunjukan bahwa Toilet, Tempat Sampah dan Tempat Ibadah menjadi sarana paling penting yang diinginkan oleh para wisatawan yang berkunjung ke Sembalun. Ini mengkonfirmasi hasil penelitian dari Permadi dkk (2015) yang meneliti tentang sarana pendukung di wisata religi di Pulau Lombok. Permadi dkk menemukan bahwa wisatawan merasa toilet dan tempat Ibadah sangat krusial untuk mereka yang sedang berwisata religi baik itu wisatawan Muslim maupun agama lain. 
Kondisi Fasilitas Wisata halal di Sembalun, Kabupaten .Lombok Timur

11. ATM bank/ penukaran...

5. Area parkir parkir bus...

12. Pelayanan kesehatan

8. Toilet

4. Zona khusus pedagang...

9. Tempat sampah

14. Pos Jaga Polisi/Satpam

7. Area parkir kendaraan...

3. Toko souvenir

6. Area parkir kendaraan...

10. Tempat istirahat...

15. Tempat hiburan

2. Restoran/tempat makan

1. Tempat ibadah

13. Hotel/akomodasi/Pengin...

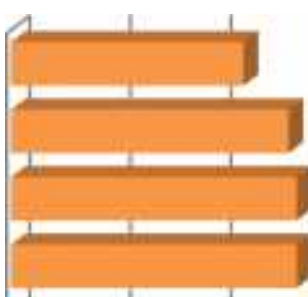

r...
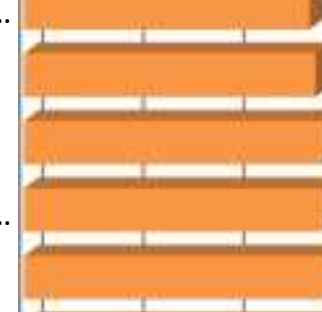

.

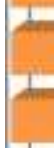

\section{L}

$$
\text { : }
$$
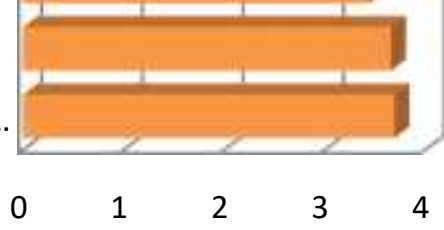

\section{Gambar 4.4. Kondisi Fasilitas Pendukung menurut responden}

Sebagian tempat wisata halal di Sembalun, Kabupaten Lombok Timur sudah memiliki fasilitas pendukung seperti Hotel, tempat ibadah, toilet, parkir dan tempat istirahat pengunjung. Pada Gambar 4.4 di atas diketahui persepsi responden tentang kondisi fasilitas wisata religi.Menurut persepsi responden penelitian ini kondisi Hotel atau akomodasi lainnya danTempat Ibadah yang ada di lokasi Wisata halal Sembalun, Kabupaten Lombok Timur sangat baik dibanding dengan kondisi dari fasilitaspendukung lainnya.ATM bank dan tempat penukaran uang dipersepsikan sangat tidak baik, ini disebabkan karena ATM bank tidak berada di lokasi wisata halal di Sembalun, Kabupaten Lombok Timurmelainkan di tempat tertentu yang ditentukan oleh pihak bank namun jauh dari tempat wisata tersebut. 
Aksesibilitas Fasilitas Wisata halal di Sembalun, Kabupaten Lombok Timur

12. ATM bank/ penukaran uang

13. Pelayanan kesehatan

9. Toilet

4. Toko souvenir

15. Pos Jaga Polisi/Satpam

10. Tempat sampah

6. Area parkir parkir bus dan...

5. Zona khusus pedagang kaki...

1. Lokasi wisata

16. Tempat hiburan

8. Area parkir kendaraan roda...

11. Tempat istirahat pengunjung

7. Area parkir kendaraan roda...

3. Restoran/tempat makan

14. Hotel/akomodasi/Penginapan

2. Tempat ibadah

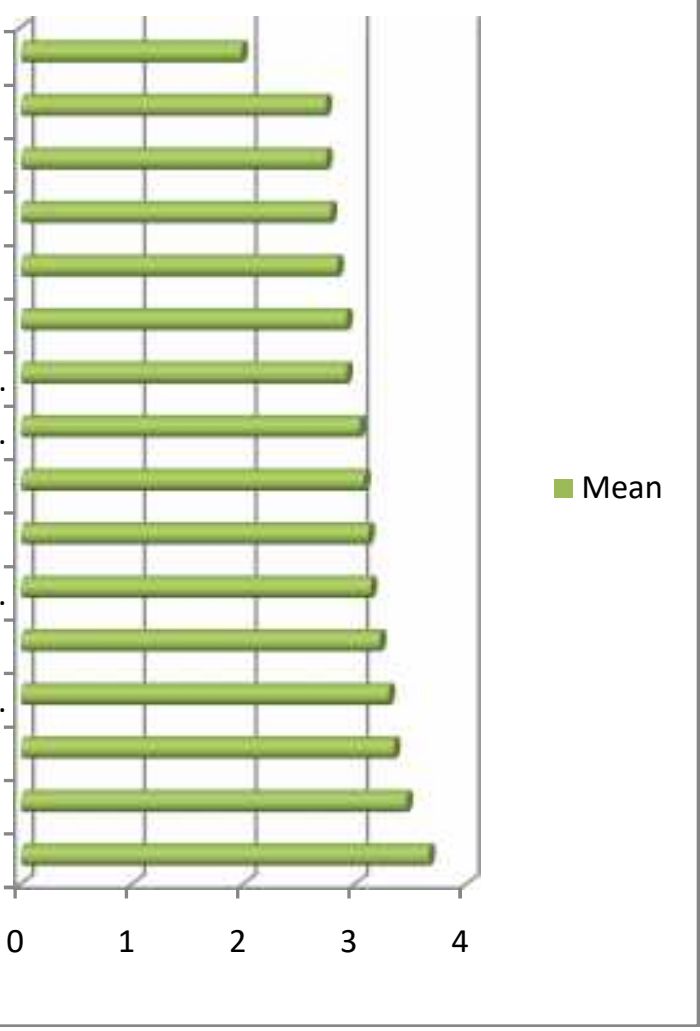

Gambar 4.5. Kemudahan akses Fasilitas Pendukung menurut responden

Dari Survei yang sudah dilakukan diketahui bahwa persepsi responden terhadap kemudahan dalam mencapai tempat lokasi wisata halal di Sembalun, Kabupaten Lombok Timurdan fasilitas yang ada di sekitamya cukup baik. Dengan kata lain aksesibiltas lokasi wisata halal di Sembalun, Kabupaten Lombok Timurdan fasilitas pendukungnya di Lombok secara rata-rata cukup baik. Menurut persepsi responden penelitian ini fasilitas yang mudah dijangkau di Sembalun Lawang adalah Tempat Ibadah, Hotel/akomodasi/Penginapan, Restoran/ tempat makan dan Area parkir kendaraan roda dua. Namun ada beberapa fasiltas pendukung yang tingkat aksesibilitasnya lebih rendah dibandingkan fasilitas yang lain. Fasilitas tersebut adalah Area parkir-parkir bus dan mini bus, Tempat sampah, Pos Jaga Polisi/Satpam, Toko souvenir, Toilet, Pelayanan kesehatan dan ATM bank/ penukaran uang. Ini menunjukkan bahwa di destinasi-destinasi wisata yang letaknya jauh dari jangkauan pemerintah kota maupun provinsi termasuk di Sembalun belum fokus memperhatikan sarana untuk parkir kendaraan rombongan wisatawan, kebersihan, kesehatan dan keamanan. Selain itu kemudahan keuangan wisatawan dengan adanya ATM juga belum terpenuhi.

\section{KESIMPULAN DAN SARAN}

\section{Kesimpulan}

Persepsi wisatawan Muslim terhadap sarana penunjang wisata Halal di kawasan SembalunLawang menurut hasil penelitian ini adalah

1. Toilet, Tempat Sampah dan Tempat Ibadah menjadi sarana paling penting yang diinginkan 


\section{$J M M$ UNRAM

oleh para wisatawan yang berkunjung ke Sembalun.

2. Kondisi Hotel atau akomodasi lainnya danTempat Ibadah yang ada di lokasi Wisata halal Sembalun, Kabupaten Lombok Timur sangat baik dibanding dengan kondisi dari fasilitas pendukung lainnya.

3. Fasilitas yang mudah dijangkau di Sembalun Lawang adalah Tempat Ibadah, Hotel/akomodasi/Penginapan, Restoran/ tempat makan dan Area parkir kendaraan roda dua.

Saran

1. Pemerintah dan masyarakat Sembalun Lawang segera menyediakan Toilet dan Tempat Sampah di setiap objek wisata di Sembalun Lawang demi kebersihan dan menariknya kawasan tersebut

2. Pemerintah harus segera mengatur hotel dan akodomasi lainnya sehingga mencukupi untuk jumlah wisatawan yang datang ke Sembalun Lawang dan tidak mengganggu pemandangan alam Sembalun sebagai andalan daerah wisata tersebut.

3. Faslilitas Parkir untuk bus wisata harus segera disediakan

4. Untuk pihak perbankan dan pemerintah harus bekerja sama dalam menyediakan fasilitas Anjungan Tunai Mandiri (ATM) sehingga memudahkan wisatawan dalam mengambil uang tunai.

\section{DAFTAR PUSTAKA}

Anonim, (2015) www.disbudpar.ntbprov.go.id, 2015

(2015) http://gayahidup.republika.co.id/ 29 Maret 2016

Arnould, E. J. (2006) Consumer culture theory: retrospect and prospect, . European Advances in $\begin{array}{llll}\text { Consumer } & \text { Research } & 7 & (1):\end{array}$ http://www.acrwebsite.org/volumes/eacr/vol7/EuropeanVolume7_105.pdf, diunduh 14 Agustus 2010.

Arnould, E. J.;and Thompson, C. J. (2005), Consumer culture theory (CCT): Twenty Years of Research, Journal of Consumer Research $31 \quad$ (4): 868882.http://econpapers.repec.org/article/ucpjconrs/v_3a31_3ay_3a2005_3ai_3a4_3ap_3a868882.htm.

Johnson, E. M., (2002) Fundamentals of Marketing, Fourth Edition, American Management Association www.flexstudy.com/demo/.../99037_toc.pdf.diunduh tanggal 19 Maret 2012

Kotler, P. dan Armstrong, G., (2008), Principles of Marketing, Prentice Hall Inc., Upper Saddle River, New Jersey.

Kotler, P. (2003),Marketing Management, 11th ed, New Jersey: Prentice Hall International Inc.

Kotler, P. dan Armstrong, G. (2001).Principle of marketing, 7th ed. New Jersey: Prentice Hall, Inc.

Kotler, P. (2000), Marketing Management, Millennium ed. New Jersey: Prentice Hall International Inc.

Rusdan dkk (2014), Persepsi dan Sikap Masyarakat Lingkar Gunung Rinjani TerhadapIndustri Pariwisata

(Suatu Upaya Menyongsong Rinjani sebagai Geopark Dunia), Laporan Penelitian, Magister Manajemen, Univ. Mataram

Schiffman, Leon. dan Kanuk, Leslie Lazar. (2008)Perilaku Konsumen (edisi ketujuh). PT. Indeks, Jakarta. Wibisono, D., (2000), Riset Bisnis edisi pertama, BPFE, Yogyakarta 